Acta vet. scand. $1976,17,307-315$.

From the National Veterinary Institute, Oslo, Norway.

\title{
THE CONCENTRATIONS OF MOLYBDENUM AND ZINC IN LIVER IN RELATION TO COPPER ACCUMULATION IN NORMAL AND COPPER POISONED SHEEP
}

\author{
By \\ Arne Frøslie and Gunnar Norheim
}

FRøSLIE, ARNE and GUNNAR NORHEIM: The concentrations of molybdenum and zinc in liver in relation to copper accumulation in normal and copper poisoned sheep. Acta vet. scand. 1976, 17, 307-315. - The concentrations of copper, molybdenum and zinc were measured in the liver of normal grazing sheep and lambs from Eastern Norway, and in sheep dead of chronic copper poisoning. The following mean values were found: Normal sheep: $173 \pm 130 \mu \mathrm{g} \mathrm{Cu} / \mathrm{g}$ wet weight, $1.0 \pm 0.3 \mu \mathrm{g} \mathrm{Mo} / \mathrm{g}$, and $49 \pm 10 \mu \mathrm{g} \mathrm{Zn} / \mathrm{g}$; lambs: $129 \pm 59 \mu \mathrm{g} \mathrm{Cu} / \mathrm{g}$, $0.9 \pm 0.3 \mu \mathrm{g} M o / g$, and $46 \pm 9 \mu \mathrm{g} \mathrm{Zn} / \mathrm{g}$; sheep dead of copper poisoning: $429 \pm 249 \mu \mathrm{g} \mathrm{Cu} / \mathrm{g}, 0.4 \pm 0.1 \mu \mathrm{g} \mathrm{Mo} / \mathrm{g}$, and $43 \pm 21 \mu \mathrm{g} \mathrm{Zn} / \mathrm{g}$. Sheep with low liver copper $(\mathrm{Cu}<10 \mathrm{\mu g} / \mathrm{g})$ were also analyzed for molybdenum and zinc, with the following results: $1.0 \pm 0.2 \mu \mathrm{g} \mathrm{Mo} / \mathrm{g}$, and $45 \pm 8 \mathrm{~g} \mathrm{Zn} / \mathrm{g}$ wet weight. The differences in liver copper between all the groups, and the differences in molybdenum concentrations between the normal sheep and the lambs and between the normal sheep and the poisoned sheep were significant $(P<0.001)$. No significant correlations between liver copper/liver molybdenum or liver copper/liver zinc were detected.

copper; molybdenum; zinc; sheep; liver; copper p o is o n ing.

Copper is both an essential and a toxic element in animal nutrition, and copper deficiency as well as toxicosis are well known in husbandry. The sensitivity to high, respectively low dietary levels of copper, however, varies greatly among animal species. Ruminants, especially sheep, are considered to be the most susceptible to copper toxicosis among domestic livestock (Underwood 1971).

It is not only the dietary content of copper which may induce copper toxicosis. Complex biological interactions between copper 
and other elements, especially molybdenum, zinc and sulphur exist (Van Campen \& Scaife 1967, Huisingh et al. 1973, 1975, Suttle 1974 a, b, Suttle et al. 1975), but are not yet fully understood.

The aim of the present investigation was to study the relationship of the copper content in sheep liver to the amount of molybdenum and zinc at different levels of copper accumulation.

\section{MATERIALS AND METHODS}

Samples of the left part of the liver of 128 sheep and 192 lambs from 16 different districts of Eastern Norway were collected at the slaughter-houses at Lillehammer, Gjøvik, Oslo and Drammen during the autumn 1974. The lambs were born in April-May 1974, while the sheep were more than one year old. The samples were analyzed for copper, molybdenum, and zinc.

In addition, data from liver analyses of 74 sheep dead of spontaneous chronic copper poisoning during 1971-1975 were included in the investigation. These sheep originated from different parts of Norway, all livers were analyzed for copper, but only 27 samples, those from 1974-1975, were analyzed for molybdenum and zinc.

For comparative reasons the liver from 20 selected sheep from ather parts of Norway with "subnormal" liver copper $(\mathrm{Cu}<10 \mu \mathrm{g} / \mathrm{g}$ wet weight) and 11 control cases dead of other diseases, but normal in liver copper, were also analyzed.

\section{Analytical methods}

The present method for the determination of molybdenum was composed from methods published in the literature (Jeffery 1956, Scharrer \& Eberhardt 1956, Schaumlöffel 1960, Oelschläger 1962, Wenger \& Högl 1971). The methods were slightly modified so that copper and zinc could be determined simultaneously. In our hands the presient variant of the dithiol method gave the mosit reproducible results for the molybdenum determinations. A critical examination of the method used is given elsewhere (Norheim \& Waasjø to be published.).

The liver samples were stored at $-18^{\circ} \mathrm{C}$ until the analyses were done. Five-g samples were digested with sulphuric acid/ nitric acid/perchloric acid until a clear solution was obtained. The acid solution was diluted to $100 \mathrm{ml}$, transferred to a dry 
separating funnel, $1 \mathrm{ml} \alpha$-benzoinoxime solution ( $2 \%$ in $96 \%$ ethanol) was added, and after a few minutes extracted with 25 $\mathrm{ml}$ chloroform. The extraction, including the addition of reagent, was repeated once. The water phase was poured back into the volumetric flask for the determination of copper and zinc by atomic absorption spectroscopy. The organic phase was collected in a digestion flask, evaporated to dryness, and the residue digested with sulphuric acid/nitric acid/perchloric acid. The remaining acid solution (about $5 \mathrm{ml}$ ) was diluted to $20 \mathrm{ml}, 1 \mathrm{ml}$ iron(II) solution ( $1 \%$ ferrous ammonium sulphate in $0.2 \mathrm{~N}$ sulphuric acid) and $2.5 \mathrm{ml}$ dithiol solution $(0.2 \%$ in $1 \%$ sodium hydroxide containing $16 \mathrm{ml}$ thioglycolic acid/l) was added, and the solution was set aside for $15 \mathrm{~min}$. Due to the reaction heat between sulphuric acid and water, the temperature during the complexation was slightly elevated. Standard solutions of molybdenum were added $5 \mathrm{ml}$ sulphuric acid, diluted to $20 \mathrm{ml}$, and treated as the samples. After cooling, the solutions were transferred to separating funnels and extracted with $5.0 \mathrm{ml}$ carbon tetrachloride. The extinctions were read in $1.0 \mathrm{~cm}$ cells at $675 \mathrm{~nm}$ against blank solution. The standard curve was a straight line up to $3 \mu \mathrm{g} \mathrm{Mo} / \mathrm{ml}$.

\section{RESULTS}

The mean values and the concentration ranges of copper, molybdenum and zinc in the liver of normal sheep and lambs are presented in Table 1. In addition the results from the analyses of liver samples from copper poisoned sheep, together with the appropriate post-mortem control samples and samples from slaughtered sheep with a liver copper concentration less than $10 \mu \mathrm{g} / \mathrm{g}$ wet weight, are also presented in the table.

The table shows that the liver copper varied greatly both within the groups and between the groups of sheep. The normal adult sheep, with a mean value of $173 \mu \mathrm{g} \mathrm{Cu} / \mathrm{g}$ wet weight, had a ratio between the largest and the smallest value of about 100 . The corresponding ratio for the lambs was about 30 . The lambs had significantly lower liver copper, with a mean value of 129 $\mu \mathrm{g} / \mathrm{g} \quad(\mathrm{P}<0.001, \mathrm{t}$-test $)$, and also a more narrow range. The range represented a difference of $812 \mu \mathrm{g} / \mathrm{g}$ in adult sheep and $332 \mu \mathrm{g} / \mathrm{g}$ in the lambs. Sheep dead of copper poisoning had an even wider range, representing a difference in copper concen- 
Table 1. Mean values and ranges of the concentrations ( $\mu \mathrm{g} / \mathrm{g}$ wet weight) of copper, molybdenum, and zinc in the liver of normal sheep and lambs, copper poisoned sheep, sheep dead of other diseases, and sheep low in liver copper $(\mathrm{Cu}<10 \mu \mathrm{g} / \mathrm{g})$.

\begin{tabular}{|c|c|c|c|c|c|c|c|}
\hline & \multirow{2}{*}{$\begin{array}{l}\text { Num- } \\
\text { bers }\end{array}$} & \multicolumn{2}{|c|}{ Copper } & \multicolumn{2}{|c|}{ Molybdenum } & \multicolumn{2}{|c|}{ Zinc } \\
\hline & & mean $\pm s$ & range & mean $\pm s$ & range & mean $\pm \mathrm{s}$ & range \\
\hline Normal adult sheep & 128 & $173 \pm 130$ & $8-820$ & $1.0 \pm 0.3$ & $0.4-2.0$ & $49 \pm 10$ & $31-110$ \\
\hline Normal lambs & 192 & $129 \pm 59$ & $8-340$ & $0.9 \pm 0.3$ & $0.3-1.6$ & $46 \pm 9$ & $26-90$ \\
\hline $\begin{array}{l}\text { Sheep dead of chronic } \\
\text { copper poisoning }\end{array}$ & 74 & $429 \pm 249$ & $150-19,00$ & $0.4 \pm 0.1^{*}$ & $0.2-0.6$ & $43 \pm 21$ * & $22-115$ \\
\hline $\begin{array}{l}\text { Sheep dead of other } \\
\text { diseases }\end{array}$ & 11 & $62 \pm 27$ & $18-120$ & $0.8 \pm 0.4$ & $0.3-1.5$ & $48 \pm 18$ & $31-93$ \\
\hline $\begin{array}{l}\text { Sheep selected for } \\
\text { low liver copper }\end{array}$ & 20 & $7 \pm$ & $3-10$ & $1.0 \pm 0.2$ & $0.7-1.4$ & $45 \pm 8$ & $35-75$ \\
\hline
\end{tabular}

* Only sheep from 1974-1975, 27 cases of poisoning, were analyzed for molybdenum and zinc.

tration of about $1750 \mu \mathrm{g} / \mathrm{g}$, but the ratio between the largest and the smallest value was only about 13 in this group of sheep. The mean value of liver copper in the poisoned animals, $429 \mu \mathrm{g} / \mathrm{g}$, was more than twice the value of adult normal sheep, and significantly greater than in any other group $(P<0.001)$. Sheep dead of other diseases had a mean value of $62 \mu \mathrm{g} \mathrm{Cu} / \mathrm{g}$ in liver, about half the level of the lambs investigated.

The concentration ranges of molybdenum in liver were, as shown in Table 1, not as wide as the ranges of the liver copper. The ratio between the largest and the smallest value for all the samples was about 10, and the maximum difference $1.8 \mu \mathrm{g} / \mathrm{g}$. The mean value of sheep, $1.0 \mu \mathrm{g} \mathrm{Mo} / \mathrm{g}$, was slightly, but significantly higher than the mean value of lambs of $0.9 \mu \mathrm{g} \mathrm{Mo} / \mathrm{g}$ wet weight $(\mathrm{P}<0.001)$, and more than twice the mean value of 0.4 $\mu \mathrm{g} / \mathrm{g}$ in the liver of copper poisoned sheep $(\mathrm{P}<0.001)$. There was, however, no difference in molybdenum concentrations between normal sheep and sheep subnormal in copper, and no significant difference between normal sheep and sheep dead of other causes than copper poisoning.

The liver concentrations of zinc showed the smallest variation of the three elements, the maximum ratio between extreme values was only about 5 . The mean concentration in normal 
sheep liver was a little higher than in lambs, 49 and $46 \mu \mathrm{g} \mathrm{Zn} / \mathrm{g}$ wet weight, respectively, but the difference was hardly significant $(0.01<\mathrm{P}<0.05)$. Among the adult sheep there were no significant differences between the different groups.

T a b l e 2. Liver concentrations of molybdenum and zinc in 128 normal sheep and 192 lambs at different class intervals of liver copper.

\begin{tabular}{|c|c|c|c|c|c|c|c|c|}
\hline & & \multicolumn{7}{|c|}{ Liver copper $\mu \mathrm{g} / \mathrm{g}$ wet weight } \\
\hline & & $0-50$ & $51-100$ & $101-150$ & $151-200$ & 201-250 & $251-500$ & 501 \\
\hline \multirow[t]{3}{*}{ Sheep } & Numbers & 13 & 24 & 32 & 21 & 12 & 19 & 7 \\
\hline & $\begin{array}{l}\text { Molybdenum, } \\
\mu \mathrm{g} / \mathrm{g} \text { wet weight }\end{array}$ & 1.1 & 1.0 & 1.0 & 0.9 & 1.0 & 1.0 & 0.8 \\
\hline & $\begin{array}{l}\text { Zinc, } \mu \mathrm{g} / \mathrm{g} \text { wet } \\
\text { weight }\end{array}$ & 51 & 48 & 48 & 47 & 48 & 50 & 51 \\
\hline \multirow[t]{3}{*}{ Lambs } & Numbers & 21 & 39 & 68 & 44 & 15 & 5 & 0 \\
\hline & $\begin{array}{l}\text { Molybdenum, } \\
\mu \mathrm{g} / \mathrm{g} \text { wet weight }\end{array}$ & 1.0 & 0.8 & 0.8 & 0.9 & 0.9 & 1.0 & - \\
\hline & $\begin{array}{l}\text { Zinc, } \mu g / g \text { wet } \\
\text { weight }\end{array}$ & 41 & 44 & 46 & 48 & 51 & 54 & - \\
\hline
\end{tabular}

Table 2 shows the mean values of molybdenum and zinc in the liver of normal sheep and lambs grouped in class intervals according to the liver copper content. The class intervals were $50 \mu \mathrm{g} \mathrm{Cu} / \mathrm{g}$ up to $250 \mu \mathrm{g} / \mathrm{g}$ liver, samples between 250 and 500 $\mu \mathrm{g} / \mathrm{g}$ constituted one group, and samples higher than $500 \mu \mathrm{g} \mathrm{Cu} / \mathrm{g}$ liver another.

As seen, there were only small and no systematic changes in molybdenum and zinc concentrations with varying liver copper content with one exception, a very slight increase in the concentrations of zinc with increasing copper levels in lamb liver. The correlation coefficient for the copper/zinc relation in lambs was, however, only 0.23 . Thus no correlation existed between copper and molybdenum, while a possible correlation between copper and zinc is found in lamb liver but not in the liver of adult sheep.

\section{DISCUSSION}

The present investigation shows that grazing sheep from Eastern Norway have a rather pronounced, but highly varied accumulation of copper in the liver. Further the study reveals 
that there is no significant correlation between the liver concentrations of molybdenum and zinc and the liver copper content.

According to Underwood (1971) the normal range of liver copper in sheep is $100-400 \mu \mathrm{g} / \mathrm{g}$ dry weight (about $30-130 \mu \mathrm{g}$ $\mathrm{Cu} / \mathrm{g}$ fresh tissue). Both that range and the normal level of copper are thus surpassed by a large margin by the present groups of sheep.

The mean values of molybdenum and zinc, however, about $1 \mu \mathrm{g} \mathrm{Mo} / \mathrm{g}$ and $45-50 \mu \mathrm{g} \mathrm{Zn} / \mathrm{g}$ wet weight, are in good accordance with the normal levels for different species (Underwood, Hapke 1975). Hellesnes et al. (1975) found mean concentrations of zinc in bovine liver from the same districts of $136 \mu \mathrm{g} / \mathrm{g}$ dry weight (about $45 \mu \mathrm{g} \mathrm{Zn} / \mathrm{g}$ wet weight).

Chronic copper poisoning in sheep may be an absolute or a conditioned poisoning, and one reason for carrying out this work was a search for a more exact aetiological diagnosis through supplementary molybdenum and zinc analyses. From that point of view the result was a negative one.

It is known that dietary molybdenum increases the copper excretion in sheep, and thus decreases the copper depots in the liver (Underwood). Contrary, it has been stated that an increased copper initake diminishes the molybdenum concentration in the liver (Havre et al. 1960). The mechanism of this antagonistic effect has been discussed in a number of papers, and recently reviewed by Huisingh et al. (1973) and Suttle (1974b). Most authors seem to agree that this interaction most probably is a ruminal or intestinal process resulting in a complex between copper and molybdenum ("cupric molybdate") which is not biologically available and therefore is excreted unchanged in the urine (Huisingh et al. 1973). These authors also give a model of interaction in the tissues, in which molybdate forms the complex with copper and thus hastens the copper excretion. These hypotheses of the antagonistic relationship between copper and molybdenum, however, are not reflected in any correlation between the two elements in the liver of sheep with varying degree of copper accumulation.

In spite of the lack of correlation between liver copper and liver molybdenum, sheep dead of chronic copper poisoning have a lower molybdenum content in the liver than sheep surviving the accumulation. This indicates that a decrease in the molybdenum concentration may occur in the terminal crisis of the 
poisoning, during which copper is released from the liver. The release of copper is possibly accompanied by a release of molybdenum too.

The interaction of zinc and copper is most probably a competitive absorption mechanism, and thus an antagonistic effect exists between the two elements (Van Campen \& Scaife 1967, Van Campen 1970, Suttle et al. 1975). From the present study it is seen that this antagonism has no consequences for the concentrations of zinc in the liver of sheep at different levels of copper accumulation.

Spontaneous cumulative copper poisoning in grazing sheep is not rare in Norway. This kind of copper poisoning was described by Nordstoga (1962), and occurs in greater parts of the country, especially in the autumn after the sheep have come back from the mountain pastures. In recent years, however, chronic copper poisoning in sheep has also occurred during the winter and spring time in connection with indoor feeding. About half the cases investigated in our laboratory from 1971 to 1975 occurred in the period January-May. The authors have put this feedrelated poisonings in connection with an increased use of concentrates and mineral supplements in sheep nutrittion, because both concentrates and mineral mixtures are added supplementary copper. Further, Todd (1972) found that oat and barley had relatively low concentrations of molybdenum and sulphur. An increase in the use of concentrates may thus increase the copper/ molybdenum and the copper/sulphur ratio, thus leading to an elevated risk for copper toxicosis. The role of the concentrates in the occurrence of chronic copper poisoning in sheep is also pointed out by Van der Berg \& Van der Schee (1973).

\section{REFERENCES}

Hapke, H.-J.: Toxikologie für Veterinärmediziner. (Toxicology for veterinarians). Ferdinand Enke Verlag, Stuttgart 1975, 248-305.

Havre, G. N., O. Dynna \& F. Ender: The occurrence of conditioned and simple copper deficiency in cattle and sheep in Setesdalen, a valley in the Southern part of Norway. Acta vet. scand. 1960, $1,250-276$.

Hellesnes, I., B. Underdal, G. Lunde \& G. N. Havre: Selenium and zinc concentrations in kidney, liver and muscle of cattle from different parts of Norway. Acta vet. scand. 1975, 16, 481-491.

Huisingh, J., G. G. Gomez \& G. Matrone: Interactions of copper, molybdenum, and sulfate in ruminant nutrition. Fed. Proc. 1973, 32, $1921-1924$. 
Huisingh, J., D. C. Milholland \& G. Matrone: Effect of molybdate on sulfide production from methionine and sulfate by ruminal microorganisms of sheep. J. Nutr. 1975, 105, 1199-1205.

Jeffery, P. G.: The simultaneous photometric determination of molybdenum and tungsten in silicate rocks. Analyst 1956, 81, 104-109.

Nordstoga, $K .:$ Unders $\varnothing$ kelser over en særlig form for kopperforgiftning hos sau. (Investigations on a special kind of copper poisoning in sheep). Proc. 9th Nord. Vet. Congr., Copenhagen 1962, 196-201.

Oelschläger, W.: Beitrag zur Bestimmung kleinster Mengen Molybdän in biologischen Substanzen mit Toluol-3,4-dithiol. (Determination of very small amounts of molybdenum in biological substances with toluene-3,4-dithiol). Z. analyt. Chem. 1962, 188, $190-194$.

Scharrer, K. \& W. Eberhardt: Zur quantitative Bestimmung kleinster Mengen Molybdän in der agrikulturchemischen Analyse. (Determination of very small quantities of molybdenum in agricultural chemical analyses). Z. Pfl-ernähr. Düng., Bodenk. 1956, 73, $115-127$.

Schaumlöffel, E.: Ưber die colorimetrische Bestimmung der Mikronährstoffe Kupfer, Zink, Kobalt, Mangan, Eisen und Molybdän aus einer Aschenlösung durch fraktionierte Extraktion. (Colourimetric determination of the micronutrients copper, zinc, cobalt, manganese, iron, and molybdenum from ash solution by fractional extraction). Landw. Forsch. 1960, 13, 278-286.

Suttle, N. F.: Effects of organic and inorganic sulphur on the availability of dietary copper to sheep. Brit. J. Nutr. 1974a, 32, $559-568$.

Suttle, N. F.: Recent studies of the copper-molybdenum antagonism. Proc. Nutr. Soc. 1974b, 33, 299-305.

Suttle, N. F., B. J. Alloway \& I. Thornton: An effect of soil ingestion on the utilization of dietary copper by sheep. J. agric. Sci. 1975, $84,249-254$.

Todd, J. R.: Copper, molybdenum and sulphur contents of oats and barley in relation to chronic copper poisoning in housed sheep. J. agric. Sci. 1972, 79, 191-195.

Underwood, E. J.: Trace elements in human and animal nutrition. 3rd Ed. Acad. Press, New York and London 1971. $543 \mathrm{pp}$.

Van Campen, D.: Competition between copper and zinc during absorption. In Trace Element Metabolism in Animals - 1. Ed.: C. F. Mills. E. \& S. Livingstone, Edinburgh and London 1970, 287296.

Van Campen, D. R. \& P. U. Scaife: Zinc interference with copper absorption in rats. J. Nutr. 1967, 91, 473-476.

Van der Berg, R. \& W. Van der Schee: Mogelijkheden ter preventie van chronische kopervergiftiging bij schapen; toevoeging van molybdeen en sulfaat aan het krachtvoeder. (Prevention of 
chronic copper poisoning in sheep, addition of molybdenum and sulphate to concentrates). T. Diergeneesk. 1973, 98, 328334.

Wenger, R. \& O. Högl: Molybdän als Spurenelement in unserer Ernährung. 2. Mitteilung. Bestimmung von geringen Molybdänmengen in Gesteinen, Böden, Gewässern, biologischem Material und Lebensmitteln. (Molybdenum as a trace element in our nutrition. 2. Determination of low-molybdenum contents in rocks, soils, water, biological materials, and foods). Mitt. Lebensmit. Hyg. 1971, 62, 1-24.

\section{SAMMENDRAG}

Molybden og sink $i$ relasjon til kobberinnholdet $i$ lever hos sau.

Molybden, sink og kobber ble bestemt i lever fra 128 voksne sauer og 192 lam fra det indre $\varnothing$ stlandsområdet i Norge. Prøvene ble innsamlet $\mathrm{i}$ forbindelse med $\mathrm{h} \phi$ stslaktingen 1974. Videre foreligger det kobberanalyser av lever fra $\mathrm{i}$ alt $\mathbf{7 4}$ tilfeller av kronisk kobberforgiftning hos sau som er diagnostisert ved Veterinærinstituttet fra 1971 til 1975. Av disse er 27 pr $\varnothing$ ver unders $\varnothing \mathrm{kt}$ for molybden og sink. Av komparative grunner ble også 20 selekterte prøver med lavt kobberinnhold fra andre deler av landet $(\mathrm{Cu}<10 \mu \mathrm{g} / \mathrm{g}$ våtvekt) og $11 \mathrm{pr} \varnothing v e r$ med „normalt“ kobberinnhold $(50-100 \mu \mathrm{g} \mathrm{Cu} / \mathrm{g})$ fra andre obduksjonskasus unders $\varnothing$ kt for molybden og sink.

Analysene viste at det er en temmelig $h \phi y$, men sterkt varierende grad av kobberakkumulering i sau fra det unders $\varnothing$ kte området. De voksne dyrene hadde høyeste verdier med et gjennomsnitt på $173 \mu \mathrm{g}$ $\mathrm{Cu} / \mathrm{g}$ våtvekt, men også lammene, som hadde et gjennomsnitt på $129 \mu \mathrm{g}$ $\mathrm{Cu} / \mathrm{g}$, lå høyere enn det som er angitt som normalverdier i litteraturen. Enkeltverdier fra presumtivt friske slaktedyr ble målt helt opp til $820 \mu \mathrm{g} \mathrm{Cu} / \mathrm{g}$ for sau og $340 \mu \mathrm{g} \mathrm{Cu} / \mathrm{g}$ for lam. Sau død av kronisk kobberforgiftning hadde et gjennomsnittlig innhold av kobber i lever på $429 \mu \mathrm{g} / \mathrm{g}$, med spredning fra 150 til $1900 \mu \mathrm{g} \mathrm{Cu} / \mathrm{g}$.

Konsentrasjonen av molybden og sink i lever fra slaktedyr, gjennomsnittlig $0,9-1,0 \mu \mathrm{g} \mathrm{Mo} / \mathrm{g}$ og $46-49 \mu \mathrm{g} \mathrm{Zn} / \mathrm{g}$ for lam respektive sau, stemmer bra med normalverdier som er angitt $i$ litteraturen. Det var ingen signifikant forskjell i molybden og sink mellom de forskjellige gruppene, bortsett fra at de kobberforgiftede dyr hadde lavere molybdeninnhold $(0,4 \mu \mathrm{g} \mathrm{Mo/g})$, noe som kan tyde på at det skjer en utskillelse av molybden fra leveren $\mathrm{i}$ forgiftningens sluttfase.

Det var ingen signifikant korrelasjon mellom leverkonsentrasjonene av molybden og kobber eller mellom sink og kobber i det foreliggende materiale.

(Received June 8, 1976).

Reprints may be requested from: The National Veterinary Institute, P.O. Box 8156, Oslo Dep., Oslo 1, Norway. 